\title{
GEORADAR INVESTIGATIONS AND GEOCHEMICAL ANALYSIS IN CONTEMPORARY ARCHEOLOGICAL STUDIES
}

\author{
Mikołaj LYSKOWSKI \& Marta WARDAS-LASOŃ \\ AGH University of Science and Technology, Faculty of Geology, \\ Geophysics and Environment Protection; \\ al. A. Mickiewicza 30, 30-059 Krakow, Poland; \\ e-mail: lyskowski@geol.agh.edu.pl,wardas.marta@gmail.com
}

\begin{abstract}
Archeological studies require a precise and interdisciplinary approach. Use of the noninvasive methods in urban area investigations is expected because they do not result in any changes in land architecture plans. Very good combination fulfilling such demands are geochemical analyses of: $\mathrm{pH}$, Eh, conductivity and heavy metals concentrations in soils and the results of the ground penetrating radar method. These methods allow for a more precise selection of places of interest and can be also used for a more accurate calibration and better interpretation of subsequent results. Proposed methodology gives good final results thanks to complementarity of each method and can be used under variable conditions.
\end{abstract}

Key words: Cracow's old town, sewage, moat, GPR, echogram, AAS, heavy metals

\section{INTRODUCTION}

The objective of this study was investigation of the environmental aspects of everyday life of the Cracow inhabitants in the medieval period. Measurements were aimed to locate and determine the course of Cracow's medieval City Moat and the historical environment pollution level. In this paper we adopt a different approach extensively employing georadar and shallow boreholes geochemical methods in archeology.

Furthermore, the obtained results were used to determine the moat location, pollution level and also to show that the geochemical and geophysical methods can complement one another.

This paper contains a short historical note, a short description of the employed research methods and the final results discussion supplemented with an explanation of the choice of employed methods. 


\section{STUDY AREA}

The Main Square of Cracow city and Planty - the park surrounding the central part of the Cracow's old city are a vital tourist destination. In the past they served a commercial function. Today's appearance is different from that of the medieval period. For example, the elevation difference between the XII century Main Square level and that of today is about $2 \mathrm{~m}$. This implies that the ground surrounding the buildings of the City Hall Tower or Sukiennice is in fact at their first floor level (Komorowski \& Sudacka 2008). In the past the Main Square was the center of production of various household tools and objects and most importantly it was a place of trade (Komorowski \& Sudacka 2008). This aspect led to numerous changes not only in its appearance, but in the area development over the years. Today, the most important aspect of this place has changed. Namely, from the city central market place the old town evolved to be a tourist attraction, center of social life and cultural events for the whole city.

The main sources of pollution in the Main Square and Planty were two now no longer existing buildings - Waga Wielka and Waga Mała. The first one was located in the south-east part of the Main Square, more precisely: west of the St. Wojciech Church and more or less opposite to the eastern entrance to the Sukiennice (the Cloth Hall). Waga Wielka was erected in the XIVth century and over the years not only its function, but also its appearance changed. However, we are most interested in its primary role. In this building heavy goods, such as copper, iron and lead, or other goods with weights over one cetnar ${ }^{1}$ were weighed, divided and sold. In 1875 the building was demolished (Komorowski \& Sudacka 2008).

In 1364 Waga Mała was erected by a decree of the Polish king Kazimierz Wielki (Casimir the Great). Its function was similar to the big sibling. Goods up to one centar were weighted inside it. This building, also called Waga Woskowa, was located in front of the houses Szara and Montelupich. Its story ends in 1801, when it was demolished (Komorowski \& Sudacka 2008).

Due to the high importance of both these buildings for the medieval Cracow trade and the manufacturing community their locations are at the core of this paper.

Our attention is focused on the wastewater removal system in medieval Cracow. In the Middle Ages sludge and impurities from workshops located around the site flew through sewage channels - Wiślna street and were discharged to the City Moat surrounding the today's old town. Figure 1 shows a schematic plan of medieval Cracow sewage channels (Czapliński et al. 2008).

From the perspective of the presented work Wiślna street has a significant importance. This street was reaching to the medieval City Moat. The sewage flowed form Waga Wielka and Waga Mała thereby causing environmental pollution. In 1533 Polish King Zygmunt I in a special decree ordered regular cleaning of all moats, which was done to allow the outflow of impurities to Zwierzyniec (Sowina 2009).

The field work was conducted at the end of Wiślna street. Boreholes and GPR profiles are marked on the map in Figure 2.

1 Big cetnar - a unit of mass equivalent to $64.8 \mathrm{~kg}$ (Komorowski \& Sudacka 2008). 


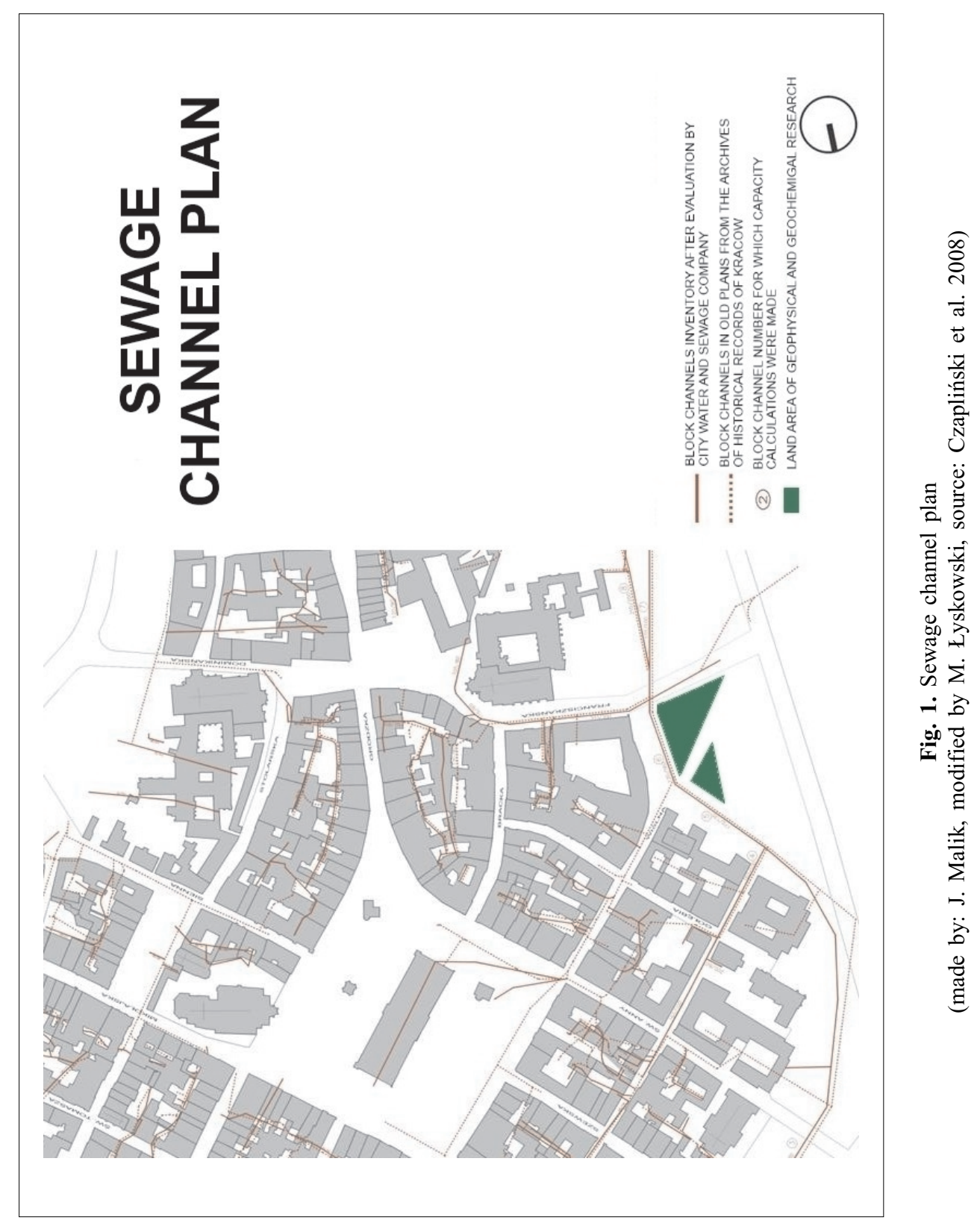




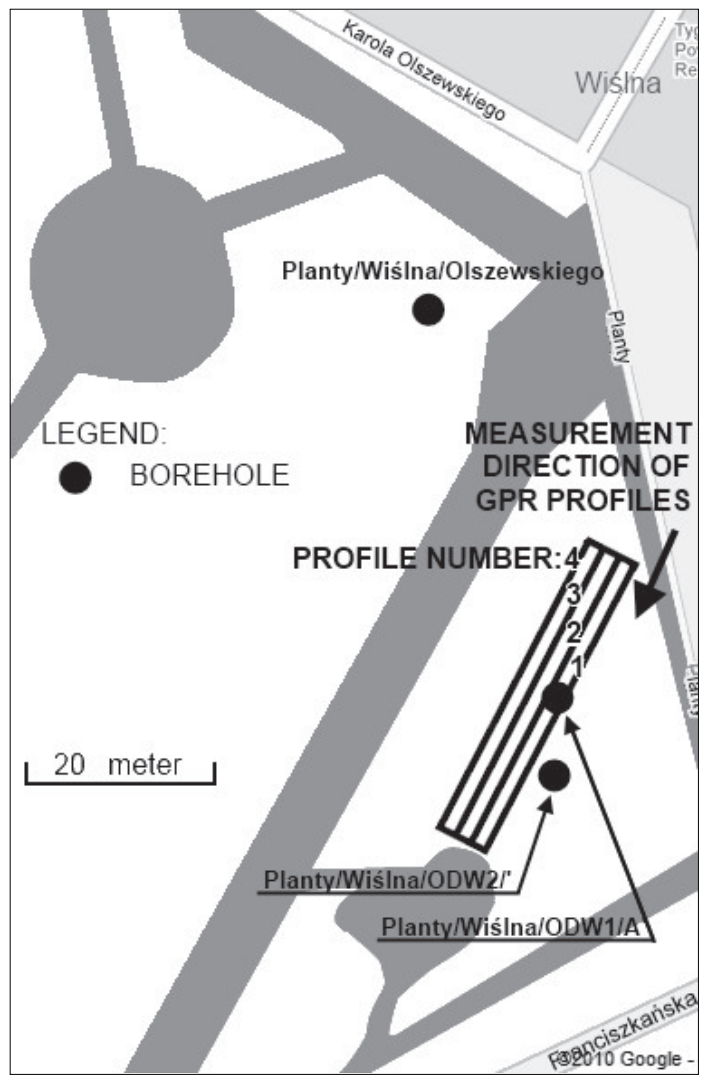

Fig. 2. Map of investigated terrain with boreholes and GPR profiles localization (source: Google Maps, modified by M. Łyskowski)

\section{RESEARCH}

Before a final choice of applied geophysical methods several of them were analyzed in terms of their capabilities and limitations. From the entire pool of methods the ground penetrating $\operatorname{radar}^{2}$ method was selected as the most appropriate one. GPR is one of the surface geophysical type of investigation, which is mostly applied in engineering geophysics. This method is a type of geophysical surface survey, in which electromagnetic waves ${ }^{3}$ within the frequency range from $10 \mathrm{MHz}$ to $6000 \mathrm{MHz}$ are emitted (Karczewski et al. 2011). Special antennas are used as sources of EM waves.

2 GPR - Ground Penetrating Radar.

3 EM - electromagnetic waves. 
Depending on the survey type two types of antennas can be used:

- shielded - usually in the form of a box, which minimizes the impact of external factors on the result and directs the electromagnetic wave into the soil;

- unshielded - usually in the form of bare dipoles, they send undirected electromagnetic waves, which makes recording of reflections from for example trees and lanterns possible (Karczewski et al. 2011).

The GPR apparatus used in surveys was manufactured by MALA Geoscience, Sweden model RAMAC / GPR with unshielded $100 \mathrm{MHz}$ antennas. This choice of antenna frequency caused the vertical resolution of about $17 \mathrm{~cm}$, and horizontal - about $25 \mathrm{~cm}$ (Noon et al. 1998). The measurement time-window was set so as to obtain coverage interpretable depths of about 11 meters below ground level. Stacking ${ }^{4}$ set at 32 .

Profiles were performed parallel one to each other with starting point sited in the same place in order to avoid echogram rotation ${ }^{5}$.

It should be mentioned that there are some disadvantages associated with the use of GPR method: its results may not always be reliable. Geological formation, which electrical parameters indicate that it is ideal for the application of this method may give poor results. And vice versa - a formation of high conductivity, where EM waves are strongly attenuated, may give very good measurement results (Wardas et al. 2010).

The selected range of geochemical studies includes basic measurements such as:

- measurement of $\mathrm{pH}$ conducted with use of Elmetron CP-104 pH meter,

- measurement of Eh - Sean ORP meter,

- conductivity measurement - Elmetron CC-103 conductivity meter.

All measurements were made in the laboratory on samples that were taken from shallow boreholes. Aqueous solutions were mixed in a mechanical shaker (Type $358 \mathrm{~S}$ ) at a mixing time of about 9 hours. Then, they were delayed for 2 hours before performed measurements.

Metal content was determined by Atomic Absorption Spectroscopy (AAS) which is based on an extraction process with the aim of separating the organic compound dissolved or suspended in water with an organic solvent. Concentrations of heavy metals were estimated by Philips PU9100 instrument. The measurement was performed on previously prepared extracts from about 1 gram of sample of sill fraction $<0.18 \mathrm{~mm}$. Weighed samples were suspended in $65 \%$ nitric acid (V), after which the prepared sample was heated at $378 \mathrm{~K}$ for 2 hours. Then, the solutions were diluted with $50 \mathrm{ml}$ of distilled water and then spun. Flame technique measurements were conducted for measuring the concentrations of lead $(\mathrm{Pb})$, copper $(\mathrm{Cu})$ and iron $(\mathrm{Fe})$.

4 Stacking (as a parameter set during the calibration of GPR) - mean amplitude value from the number of pulses emitted at the same point of measurement, which result in a better and clearer trace (without background noise).

5 Echogram - a form of visualization of GPR measurements based on the visual scoring of the amplitude of reflected waves from the boundaries having different dielectric constant as a function of time; rock depth is obtained by converting the wave propagation time in the resort and the adopted velocity profiles of tabular or WARR profiling (Karczewski et al. 2011). 


\section{RESULTS}

Prior to the presentation of the echograms of GPR profiles (echograms) they should be processed. For this purpose a computer program ReflexW, version 5.5 and the procedure with the following steps were employed:

- move starttime - offset relative to zero to signal in advance;

- subtract-DC-shift - to remove the impact of electronics;

- background removal - to remove noise from echogram;

- bandpassfrequency - 4-pole frequency filter;

- manual gain (s) - echogram hand strengthening agent made to enhance the reflexes;

- div. compensation - compensation filtering divergence geometry;

- xy-average filter - mean calculated from a given set of samples.

Geochemical data were grouped in graphs made with Grapher 5 program. The results are summarized in Figures 3 and 4.

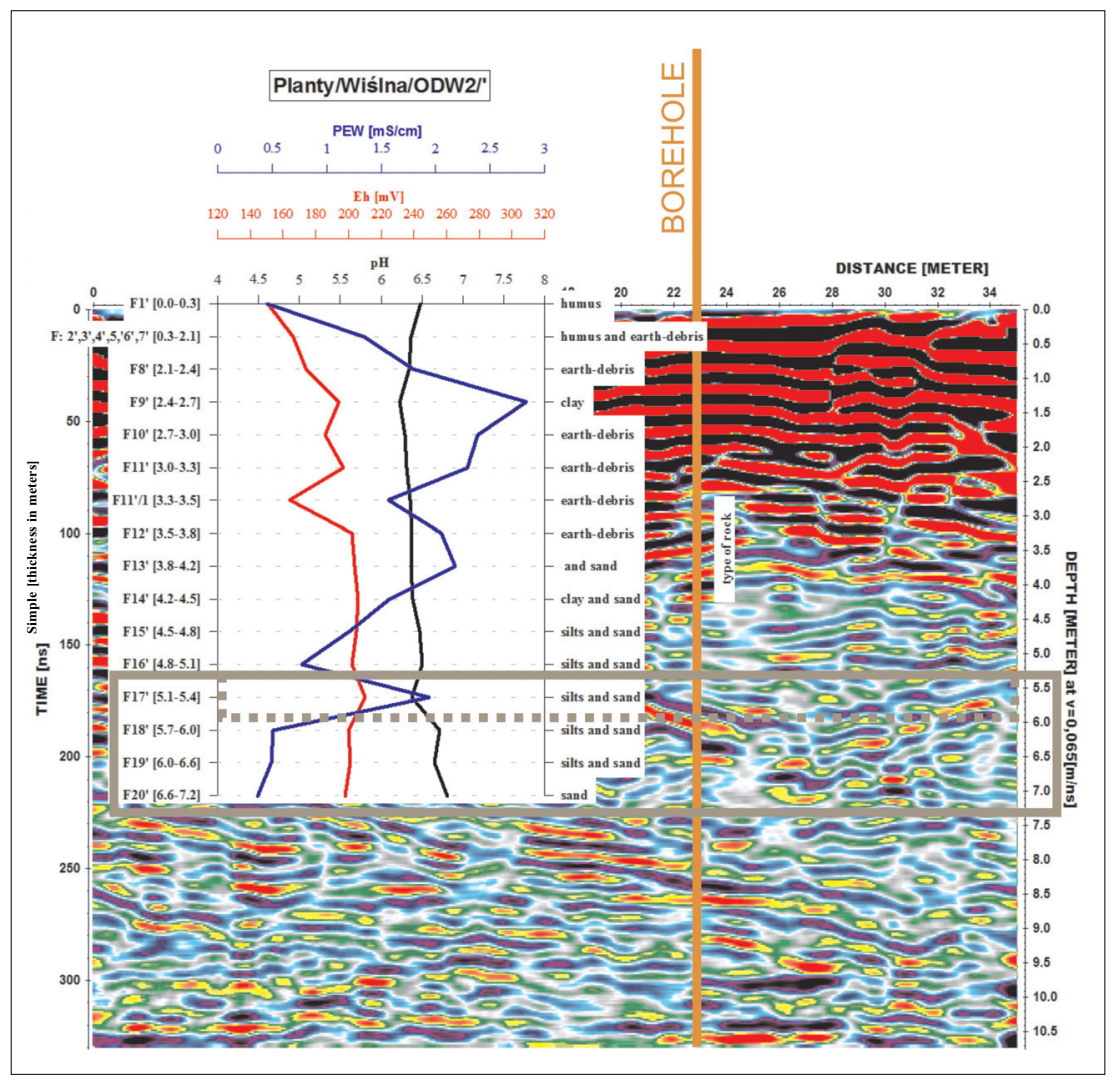

Fig. 3. Echogram from GPR profile number 3 with $\mathrm{pH}$, Eh and conductivity graph from borehole Planty/Wiślna/ODW2/, 


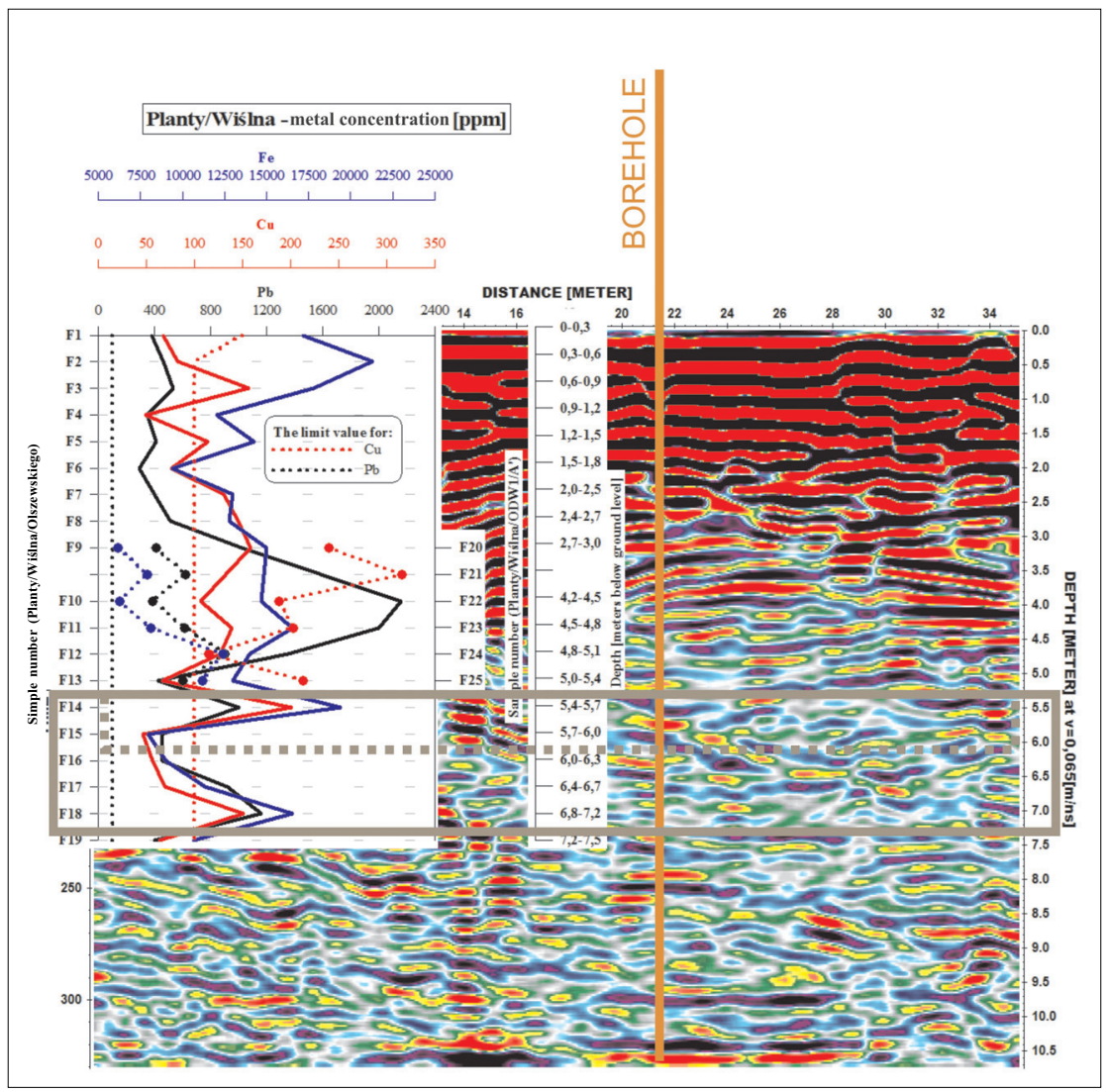

Fig. 4. Echogram from GPR profile number 4 with metal concentration graph

Plots presenting changes of geochemical parameters vs. depth and georadar anomalies (Figs 3,4) illustrate the ancient course of the City Moat. The most interesting anomalies are observed at the depth of 5.4-5.7 m. We interpret the anomalies as related to Medieval metal remnants transported with sewage from Waga to the Moat. Distinct increase of conductivity is observed in the mentioned depth section in Figure 4. On the basis of this geochemical anomaly we expected that the GPR method should provide good results. This was confirmed as weak GPR anomalies are observed in the discussed place.

\section{DISCUSSION}

The obtained results may be analyzed in several ways. However, as previously mentioned, the most interesting aspect is the correlation of the results of geochemical measurements and ground penetrating radar method and their ability to complement each other. 
The obtained data shows that the choice of methods was appropriate, also they are of good quality and complement each other. From the point of view of applied geophysics, a knowledge of the investigated medium allows us to adopt a more accurate value of the electromagnetic wave propagation velocity in the medium, and thus get a better conversion of time scale to depth scale. In the opposite case, a GPR investigation allowed for a better selection of the implementation of shallow wells for.

At this point the possibility of using other methods of engineering geophysics should be discussed. An equally good choice, if not a better one, would be the method of resistivity imaging. However, considering space requirements the application of this method would be problematic. Consideration also may be given to selection of other antennas for the GPR method. However, previously conducted ground reconnaissance surveys showed that the choice of shielded antennas $(500 \mathrm{MHz})$ and other unshielded antennas $(200 \mathrm{MHz})$ was not quite appropriate. The results were of inferior quality or even the expected moat did not show any anomalies.

Togheter with used geochemical methods there were performed measurements of grain size distribution and concentration of cations. Unfortunately, these results did not significantly affect the analysis of this type of interdisciplinary research.

\section{CONCLUSION}

- In terms of archaeological research geophysical and geochemical methods harmonize and complement each other.

- Geochemical methods require auger drilling that allow us to gain the direct access to the soils and enable identification of the rock through the collected samples by a study of basic physicochemical properties.

- The GPR method has proved to be suitable for the study purposes, however specific properties of the investigated soil, especially in urban areas, such as water content, ground type (natural or embankment), should be taken into account.

- The disadvantage of both methods is the need for sizeable financial effort and time, but their cooperation helps to reduce the impact of these aspects.

- Combining both methods allows for the determination of the exact location, selected parameters and finally the conclusion of the course of a moat: the bottom of the City Moat is at about 6-7 m below ground level. Contaminated sediment thickness varies from $0.6 \mathrm{~m}$ to $1.2 \mathrm{~m}$.

The study was carried out within the research project funded by the Polish Ministry of Science, N 525014 32/1746 (18.18.140.563-AGH) Identification of historical sequence layers (strata) and underground infrastructure of Cracow, Casmir and their suburbs, in relation to the revaluation of relics of the past, and to the 750 anniversary of the location of the city. The work was carried out in 2006-2010 under the direction of Marta Wardas-Lason. 


\section{REFERENCES}

Czapliński T., Malik J. \& Dąbrowski W., 2008. Kanały blokowe Krakowa w ujęciu historycznym i obecnie. [in:] Wardas M. \& Pawlikowski M (red.), Nawarstwienia historyczne Krakowa. Forum Naukowe 2007, Uczelniane Wydawnictwa Naukowo-Dydaktyczne AGH, Kraków, 57-71.

Karczewski J., Ortyl Ł. \& Pasternak M., 2011. Zarys metody georadarowej (wydanie 2 poprawione i rozszerzone). Wydawnictwa AGH, Kraków.

Komorowski W. \& Sudacka A., 2008. Rynek Główny. Zakład Narodowy im. Ossolińskich Wydawnictwo we Wrocławiu, Wrocław.

Noon D.A., Stickley G.F. \& Longstaff D., 1998. A frequency-independent characterization of GPR penetration and resolution performance. Journal of Applied Geophysics, 40(1-3), 127-137.

Rozporzqdzenie Ministra Środowiska z dnia 9 września 2002 r. w sprawie standardów jakości gleby oraz standardów jakości ziemi. Dz. U. z 2002 r. nr 165, poz. 1359.

Sowina U., 2009. Woda i ludzie w mieście późnośredniowiecznym i wczesnośredniowiecznym. Instytut Archeologii i Etnografii, Warszawa.

Wardas M., Ziętek J., Łyskowski M. \& Tabaszewski W., 2010. Możliwość wykorzystania zanieczyszczenia miedzią i ołowiem osadów w nawarstwieniach archeologicznych Krakowa do wyznaczania lokalizacji historycznych kolektorów ścieków. [in:] Rajchel J. (red.), Jubileusz Katedry Geologii Ogólnej, Ochrony Środowiska i Geoturystyki Akademii Górniczo-Hutniczej 1920-2010, Wydawnictwa AGH, Kraków. 
